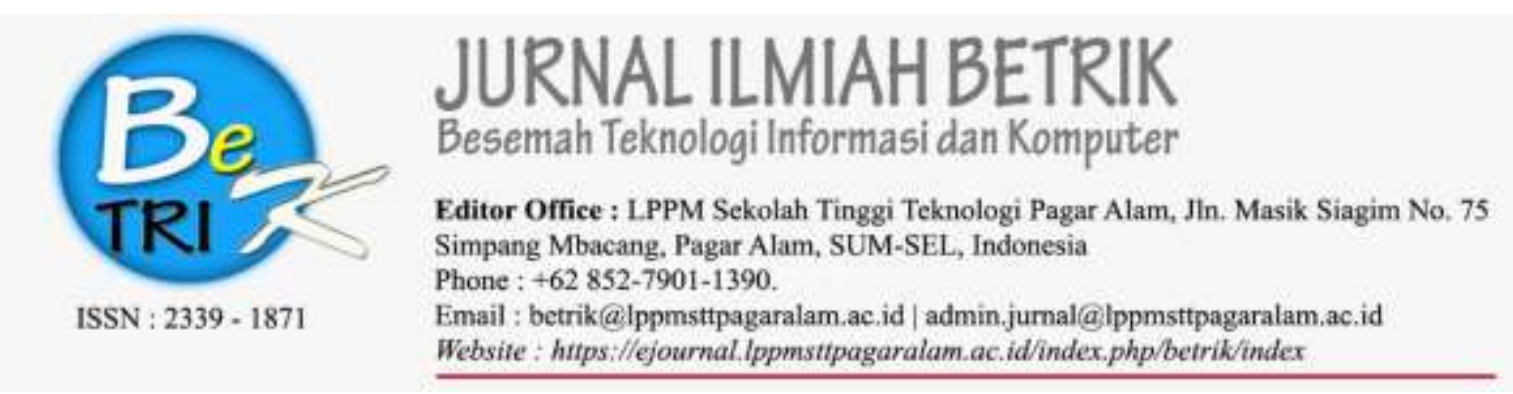

\title{
SISTEM INFORMASI PADA MTS GUPPI KOTA PAGAR ALAM BERBASIS WEB
}

\author{
Alfis Arif \\ Program Studi Teknik Informatika Sekolah Tinggi Teknologi Pagar Alam ${ }^{12}$ \\ JalanMasik Siagim No.75 Simpang Mbacang Kec.Dempo Tengah Kota Pagar Alam \\ Sur-el : alfisarif@yahoo.com
}

\begin{abstract}
Abstrak: Teknologi informasi dapat dikatakan salah satu contoh produk teknologi yang berkembang pesat yang dapat membantu manusia dalam mengolah data, menyimpan data serta menyajikan sebuah informasi yang berkualitas. Penyampaian informasi yang dilakukan oleh MTs menggunakan sebuah spanduk dan informasi lisan. Dengan cara tersebut peyebaran informasi mengenai MTs dirasa kurang efektif, karena dapat menyebabkan terlambatnya penyebaran informasi dan pembuatan laporan. Penyebaran informasi tersebut akan dirasakan lebih efektif apabila MTs memiliki sistem informasi website sebagai salah satu media penyimpanan dan penyampaian informasi kepada masyarakat. Rancang bangun sistem informasi dalam pembuatan website di MTs GUPPI kota Pagar Alam ini menggunakan metode Engineering dengan tools UML (Unified Modeling Language) dengan menggunakan diagram antara lain use case diagram, activity diagram, sequence diagram, dan class diagram. Bahasa pemerograman yang digunakan adalah PHP dan MySQL sebagai basis datanya. Dari hasil penelitian ini menghasilkan sebuah website yang berfungsi untuk memudahkan dalam pencarian informasi di MTs GUPPI kota Pagar Alam.
\end{abstract}

Kata Kunci : Sistem Informasi, MTs GUPPI, UML, Web Engineering, PHP dan MySQL.

\begin{abstract}
Information technology can be said one example of a rapidly evolving technology Products that can assist people in processing data, store data and present a quality infomation. Submission of information made by MTs using a banner and oral information. In this way the information dissemination of MTs is less effective, because it can lead to delayed dissemination of information and reporting. The dissemination of information will be felt more effectively if the MTs has a website information system as one of the storage and delivery of information to the public. The design of information system in making website in MTs Guppi Pagar Aalam City uses Engineering method with UML (Unified Modelling Language) tool by using diagrams such as use case diagram, activity diagram, sequence diagram, and class diagram, . The programming language used is PHP and MySQL as its data base. From the results of this study result a website that serves to facilitate the search for information on MTs GUPPI Pagar Alam city.
\end{abstract}

Keywords: System Information, MTs GUPPI, UML, Web Engineering, PHP and $\quad M Y S Q L$

\section{PENDAHULUAN}

Pengembangan jaringan komunikasi data antar

komputer menjadikan internet muncul dengan berbagai macam aplikasi. Informasi yang diperoleh dari internet pun bermacam-macam tergantung dari informasi yang dibutuhkn user (pemakai). Salah satu Informasi yang dapat kita peroleh adalah banyaknya situs-situs pendidikan 
mulai dari tingkatan umum (SMP) sampai degan tingkat kampus akademik. Oleh itu, dengan berkembangnya kemajuan teknologi ini, Smp Azharyah Palembang perlu mempromosikan dirinya melalui sebuah website yang online di internet. Dengan sebuah website yang online di internet, masyarakat dapat dengan mudah mengakses dan mengetahui segala sesuatu mengenai SMP Azharyah Palembang dengan cepat tanpa memerlukan waktu yang banyak.Dalam penelitian ini dihasilkan sebuah website SMP Azharyah Palembang yang menyajikan informasi tentang sekolah yang memuat dalam tampilan menu home, sejarah, profil, visi misi, struktur organisasi, staff pengajar, ekstrakulikuer, galeri, kontak, berita, agenda dan fasilitas. (Oktaviani, 2015)

Berdasarkan hasil observasi yang telah dilakukan pada MTs GUPPI didapat bahwa saat ini di MTs masih belum memiliki sistem informasi sebagai media penyampaian informasi dan promosi. Untuk saat ini penyampaian informasi yang dilakukan oleh MTs menggunakan sebuah spanduk dan informasi lisan. Dengan cara tersebut peyebaran informasi mengenai MTs dirasa kurang efektif, karena dapat menyebabkan terlambatnya penyebaran informasi dan pembuatan laporan. Penyebaran informasi tersebut akan dirasakan lebih efektif apabila MTs memiliki sistem informasi website sebagai salah satu media penyimpanan dan penyampaian informasi kepada masyarakat.

Dari latar belakang diatas dapat disimpulkan bahwa sistem informasi berbasis Web dapat membantu MTs dalam penyampaian sebuah informasi, juga dapat digunakan MTs untuk mempromosikan MTs ke masyarakat luas. Oleh karena itu, sistem informasi berbasis Web yang akan dibuat sangat membatu MTs untuk mempromosikan MTs supaya dikenal oleh masyarakat luas.

Berdasarkan latar belakang diatas dan penelitian terdahulu didapatkan analisis kebutuhan yang dibutuhkan oleh MTs GUPPI adalah sebuah sistem informasi web yang efektif dan efesien untuk media penyimpanan dan penyampaian informasi kepada masyarakat. Maka dengan ini peneliti mengambil judul "Sistem Informasi Pada Mts Guppi Kota Pagar Alam Berbasis Web".

\section{METODE PENELITIAN}

\subsection{Metode Pengembangan Sistem}

Metodelogi pengembangan sistem pada penelitian ini menggunakan model proses $\mathrm{Web}$ Engineering seperti yang terlihat pada gambar dibawah ini. (Nugroho, 2004). Berikut adalah gambar Web Engineering:

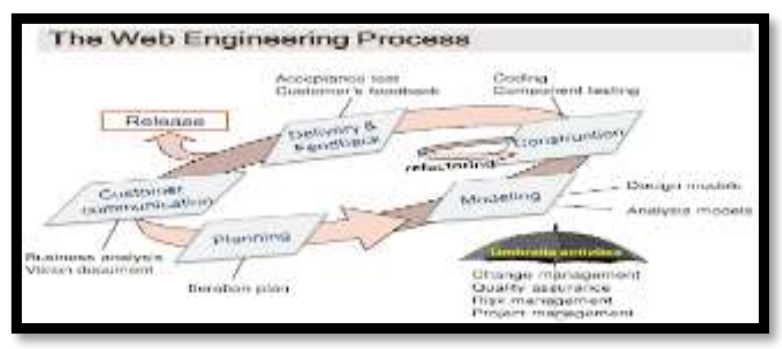

Gambar 1: Tahapan-Tahapan Proses Web Engineering

Tahapan tersebut antara lain:

1. Customer Comunication (komsunikasi dengan pengguna)

Pada proses WebE, komunikasi dengan pengguna dikarakteristikkan dengan dua aktivitas utama: analisa bisnis dan formulasi. Analisa bisnis didfinisikan berkaitan dengan konteks bisnis/organisasi yang berkaitan dengan WebApp. Selanjutnya, stakeholders 
diidentifikasikan, perubahan iklim bisnis yang potensial atau permintaan pasar diprediksi, dan integrasi antara WebApp dan aplikasi bisnis lainnya, database, dan fungsi diidentifikasikan. Formulasi adalah sebuah aktifitas pengumpulan kebutuhan yang melibatkan seluruh stakeholders. Tujuannya adalah untuk mendeskripsikan masalah yang perlu diselesaikan engan menggunakan informasi yang ada.

\section{Planning (perencanaan)}

Perencanaan dilakukan dari definisi tugas dan jadwal pekerjaan untuk jangka waktu tertentu yang diproyeksikan untuk peluncuran WebApp.

\section{Modelling (pemodelan)}

Teknik software konvensional menganalisa dan mendesain tugas yang di adaptasikan untuk mengembangkan WebApp, menggabungkan, dan kemudian menyatukannya dalam kegiatan pemodelan WebE. Tujuannya adalah untuk menggembangkan analisa "cepat" dan mendesain model yang menetapkan kebutuhan dan pada waktu yang sama merepresentasikan sebuah WebApp yang akan memuaskan mereka.

\section{Construction (konstruksi)}

Perangkat WebE dan teknologinya diaplikasikan untuk membuat WebApp yang telah jadikan model. Pada saat WebApp telah dibuat, serangkaian tes yang cepat dilakukan untuk mengukur kesalahan dalam desain tersebut.

5. Deployment (penyebaran)

WebApp dikonfigurasikan untuk lingkup operasionalnya, diluncurkan pada para penguna akhir, dan kemudian adanya tahap evaluasi. Umpan balik disaikan pada tim WebE, dan perbaikan dilakukan sesuai kebutuhan.

\subsection{USE CASE DiagRAM}

Use case mendeskripsikan sebuah interaksi antar satu atau lebih aktor dengan sistem informasi yang akan dibuat. Use case digunakan untuk mengetahui fungsi apa saja yang ada didalam sebuah sistem informasi dan siapa saja yang berhak menggunakan fungsifungsi itu. Use Case diagram Admin diharuskan melakukan login dan dihadapkan pada beberapa menu pilihan seperti input data sekolah, input data guru, input data siswa, input data profil, data informasi dan data galeri, atur buku tamu dan atur tampilan web, untuk user bisa melihat web. Use case diagram bisa dilihat pada gambar dibawah ini:

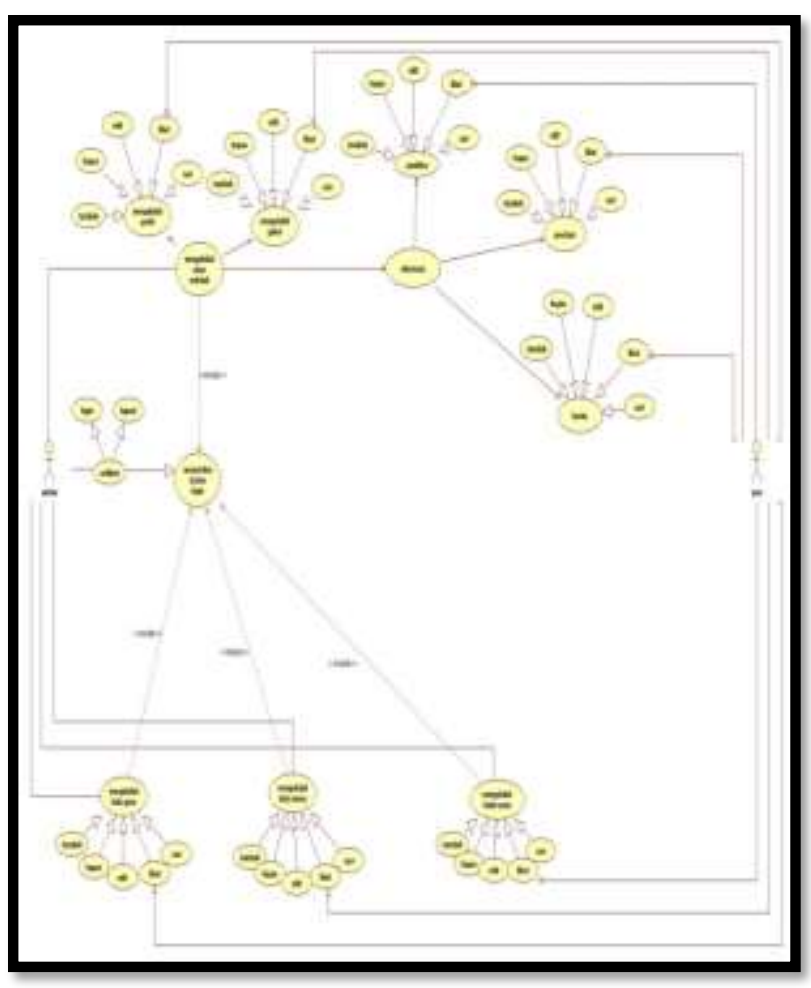

Gambar 2. Use Case Diagram yang diusulkan 


\subsection{Class Diagram}

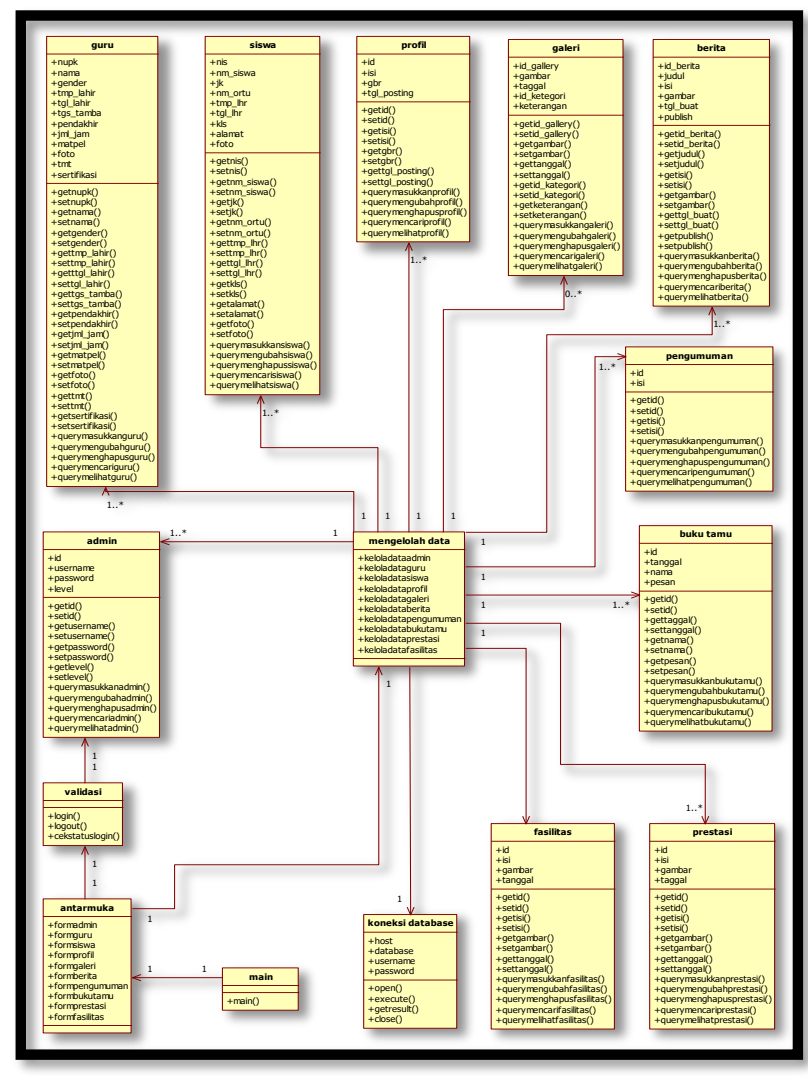

Gambar 3. Class Diagram Sistem

\subsection{Desain Tabel}

\section{Tabel Login Admin}

\begin{tabular}{cllll}
\hline No & Name & Type & Size & Keterangan \\
\hline 1 & Id & int & 4 & identitas \\
\hline 2 & Username & Varchar & 25 & \\
\hline 3 & Password & Varchar & 25 & kata sandi \\
\hline 4 & Level & Varchar & & Level \\
\hline
\end{tabular}

\section{Tabel Guru}

\begin{tabular}{|c|c|c|c|c|}
\hline No & Name & Type & Size & Keterangan \\
\hline 1 & nupk* & $\begin{array}{l}\text { varch } \\
\text { ar }\end{array}$ & 15 & nupk \\
\hline 2 & nama & $\begin{array}{l}\text { varch } \\
\text { ar }\end{array}$ & 35 & nama guru \\
\hline 3 & gender & $\begin{array}{l}\text { varch } \\
\text { ar }\end{array}$ & 15 & jenis kelamin \\
\hline 4 & tmp_lhr & $\begin{array}{l}\text { varch } \\
\text { ar }\end{array}$ & 25 & tempat lahir \\
\hline 5 & tgl_lhr & date & & tanggal lahir \\
\hline 6 & $\begin{array}{l}\text { tgs_tamb } \\
\text { a }\end{array}$ & $\begin{array}{l}\text { varch } \\
\text { ar }\end{array}$ & 20 & tugas tambahan \\
\hline 7 & $\begin{array}{l}\text { pendakhi } \\
\mathrm{r}\end{array}$ & $\begin{array}{l}\text { varch } \\
\text { ar }\end{array}$ & 25 & $\begin{array}{l}\text { pendidikan } \\
\text { terakhir }\end{array}$ \\
\hline 8 & jml_jam & $\begin{array}{l}\text { varch } \\
\text { ar }\end{array}$ & 15 & jumlah jam \\
\hline 9 & matpel & $\begin{array}{l}\text { varch } \\
\text { ar }\end{array}$ & 30 & mata pelajaran \\
\hline 10 & matpel1 & $\begin{array}{l}\text { varch } \\
\text { ar }\end{array}$ & 30 & mata pelajaran 1 \\
\hline 11 & matpel2 & $\begin{array}{l}\text { varch } \\
\text { ar }\end{array}$ & 30 & mata pelajaran 2 \\
\hline 12 & matpel2 & $\begin{array}{l}\text { varch } \\
\text { ar }\end{array}$ & 30 & mata pelajaran 3 \\
\hline 13 & kls & $\begin{array}{l}\text { varch } \\
\text { ar }\end{array}$ & 15 & kelas \\
\hline 14 & kls 2 & $\begin{array}{l}\text { varch } \\
\text { ar }\end{array}$ & 15 & kelas 2 \\
\hline 15 & foto & $\begin{array}{l}\text { varch } \\
\text { ar }\end{array}$ & 150 & foto \\
\hline 16 & $\operatorname{tmt}$ & date & & tamat \\
\hline 17 & $\begin{array}{l}\text { sertifikas } \\
\mathrm{i}\end{array}$ & $\begin{array}{l}\text { varch } \\
\text { ar }\end{array}$ & 15 & sertifikasi \\
\hline
\end{tabular}

3. Tabel Siswa

\begin{tabular}{cllcl}
\hline No & Name & Type & Size & Keterangan \\
\hline 1 & Nis* & Int & 20 & $\begin{array}{l}\text { Nomor Induk } \\
\text { Siswa }\end{array}$ \\
\hline 2 & $\begin{array}{l}\text { Nm_ } \\
\text { siswa }\end{array}$ & Varchar & 25 & Nama Siswa \\
\hline 3 & Jk & Varchar & 2 & Jenis Kelamin \\
\hline
\end{tabular}




\begin{tabular}{cllcl}
\hline No & Name & Type & Size & Keterangan \\
\hline 4 & $\begin{array}{l}\text { Nm_ } \\
\text { ortu }\end{array}$ & Varchar & 25 & $\begin{array}{l}\text { Nama orang } \\
\text { tua siswa }\end{array}$ \\
\hline 5 & $\begin{array}{l}\text { Tmp } \\
\text { _lhr }\end{array}$ & Varchar & 25 & Tempat Lahir \\
\hline 6 & $\begin{array}{l}\text { Tgl_l } \\
\text { hr }\end{array}$ & Date & Tanggal Lahir \\
\hline 7 & Kelas & Varchar & 10 & Kelas \\
\hline 8 & $\begin{array}{l}\text { Alam } \\
\text { at }\end{array}$ & Varchar & 25 & Alamat \\
\hline 9 & Foto & Varchar & 50 & Foto Siswa \\
\hline
\end{tabular}

\section{Tabel Profil}

\begin{tabular}{lllll}
\hline No & Name & Type & Size & Keterangan \\
\hline 1 & Id $^{*}$ & Int & 4 & Id \\
\hline 2 & Isi & Text & & Isi profil \\
\hline 3 & Gbr & Varchar & 50 & Gambar profil \\
\hline 4 & $\begin{array}{l}\text { tgl_p } \\
\text { osting }\end{array}$ & Date & & $\begin{array}{l}\text { Tanggal } \\
\text { posting }\end{array}$ \\
\hline
\end{tabular}

\section{Tabel Galeri}

\begin{tabular}{cllll}
\hline No & Name & Type & Size & Keterangan \\
\hline 1 & Id_gallery* & Int & 4 & Id_galeri \\
\hline 2 & gambar & $\begin{array}{l}\text { Varch } \\
\text { ar }\end{array}$ & 100 & gambar \\
\hline 3 & Tanggal & Date & $\begin{array}{l}\text { Tanggal } \\
\text { posting } \\
\text { gambar }\end{array}$ \\
\hline 4 & id_kategori & int & 3 & $\begin{array}{l}\text { identitas } \\
\text { kategori }\end{array}$ \\
\hline 5 & keterangan & text & & keterangan \\
\hline
\end{tabular}

\section{Tabel Berita}

\begin{tabular}{lllll}
\hline No & Name & Type & Size & Keterangan \\
\hline 1 & $\begin{array}{l}\text { Id_berita } \\
*\end{array}$ & Int & 4 & Id_berita \\
\hline 2 & Judul & Varchar & 100 & Judul \\
\hline 3 & Isi & Text & & Isi \\
\hline 4 & Gambar & Varchar & 150 & Gambar \\
\hline 5 & Tgl_buat & Date & & Tanggal buat \\
\hline 6 & Publish & Char & 1 & Publish
\end{tabular}

\section{Tabel Buku Tamu}

\begin{tabular}{lllll}
\hline No & Name & \multicolumn{1}{c}{ Type } & Size & Keterangan \\
\hline 1 & $\mathrm{Id}^{*}$ & Int & 10 & $\mathrm{Id}$ \\
\hline 2 & Tanggal & Date & & Tanggal \\
\hline 3 & Nama & Varchar & 25 & Nama
\end{tabular}

\begin{tabular}{cllll}
\hline No & Name & Type & Size & Keterangan \\
\hline 4 & email & Varchar & 30 & Email \\
\hline 5 & Pesan & Text & & Pesan \\
\hline
\end{tabular}

\section{Tabel Prestasi}

\begin{tabular}{cllll}
\hline No & Name & Type & Size & Keterangan \\
\hline 1 & Id $^{*}$ & Int & 11 & Id_Prestasi \\
\hline 2 & Isi & Text & & Isi \\
\hline 3 & Gambar & Varchar & 25 & Gambar \\
\hline 4 & Tanggal & Date & & Tanggal \\
\hline
\end{tabular}

\section{Tabel Fasilitas}

\begin{tabular}{lllll}
\hline $\begin{array}{l}\text { N } \\
\text { o }\end{array}$ & Name & Type & Size & Keterangan \\
\hline 1 & Id * & Int & 11 & Id_Fasiitas \\
\hline 2 & Isi & Text & & Isi Fasilitas \\
\hline 3 & Gambar & Varch & 20 & Gambar \\
\hline 4 & Tanggal & Date & & Tanggal \\
\hline
\end{tabular}

\subsection{Desain Halaman}

Rancangan halaman utama merupakan tampilan pertama saat kita membuka web MTs. Rancangan halaman utama dapat kita lihat seperti gambar dibawah ini :

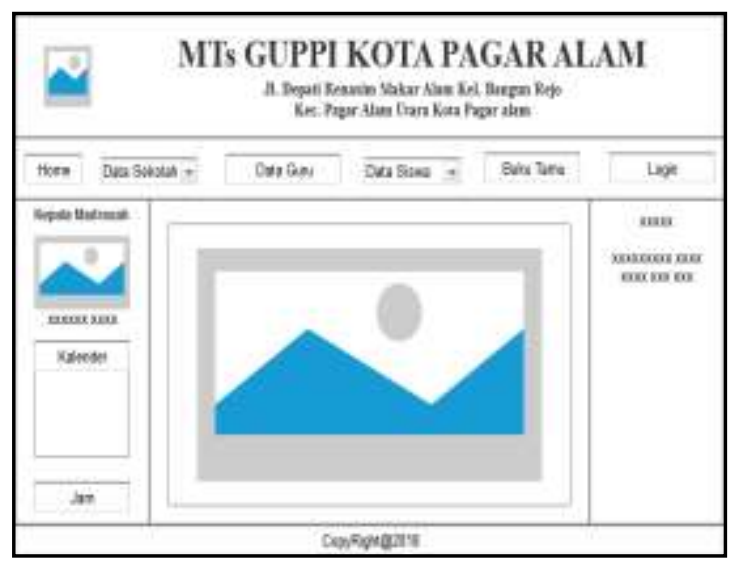

Gambar 4 Desain Halaman Utama

\subsection{Desain Tampilan Halaman Login Admin}

Rancangan Halaman Login Admin merupakan halaman yang digunakan untuk login ke dalam sistem, sehingga dapat 
melakukan pengolaan terhadap sistem yang akan di kelola oleh admin

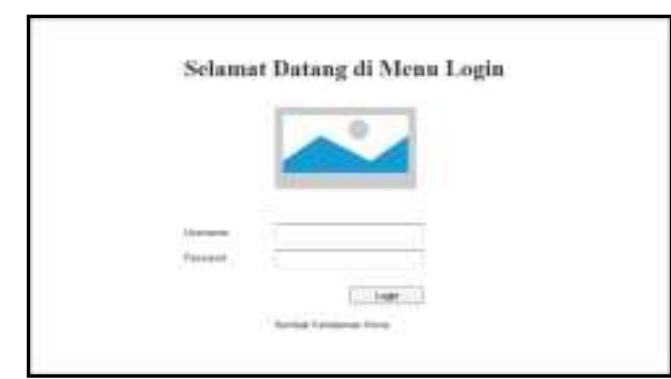

Gambar 5. Desain Tampilan Halaman Login Admin

\subsection{Tampilan Menu Admin}

Halaman menu Admin ini berfungsi untuk melakukan pengolaan terhadap sistem sehingga dapat melakukan pengolaan terhadap sistem yang akan di kelola oleh Admin

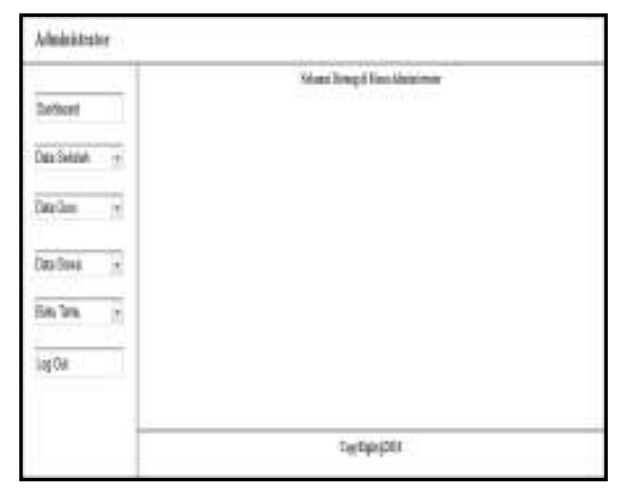

Gambar 6. Desain Tampilan Menu Admin Tamu

\section{HASIL DAN PEMBAHASAN}

\subsection{Hasil}

Hasil penelitian untuk Rancang Bangun Sistem Informasi Pada Mts Guppi Kota Pagar Alam Berbasis Web. Sistem ini dibuat dengan menggunakan pemrograman PHP dengan Adobe Dreamweaver CS3 untuk design dan MySQL sebagai pendukung untuk pembuatan database sehingga menghasilkan sebuah Sistem Informasi Pada Mts Guppi Kota Pagar Alam Berbasis Web.

Bahasa Pemrograman merupakan tahap untuk sistem supaya siap dioperasikan, termasuk kegiatan penulisan kode program yang berguna. Pada tahap ini sistem yang telah dirancang siap dioperasikan dengan keadaan yang sebenarnya, sehingga dapat diketahui apakah sistem sudah benar-benar sesuai dengan apa yang diinginkan. Sistem informasi yang dibuat berupa Input data siswa, guru, profil, galeri foto, fasilitas, prestasi, berita, buku tamu, dan data pengumuman. Output berupa informasi data tersebut. Alamat Akses web: guppi.000webhostapp.com

\subsection{Pembahasan}

Berikut ini adalah pembahasan dari hasil uji coba atau testing Rancang Bangun Sistem Informasi Pada Mts Guppi Kota Pagar Alam Berbasis Web, baik dari admin dan user. berikut ini adalah tampilan dari masing masing menu yang ada pada Rancang Bangun Sistem Informasi Pada Mts Guppi Kota Pagar Alam Berbasis Web.

\subsubsection{Halaman Utama}

Halaman utama merupakan tampilan pertama saat kita membuka web MTs. Tampilan halaman utama dapat kita lihat seperti gambar dibawah ini : 


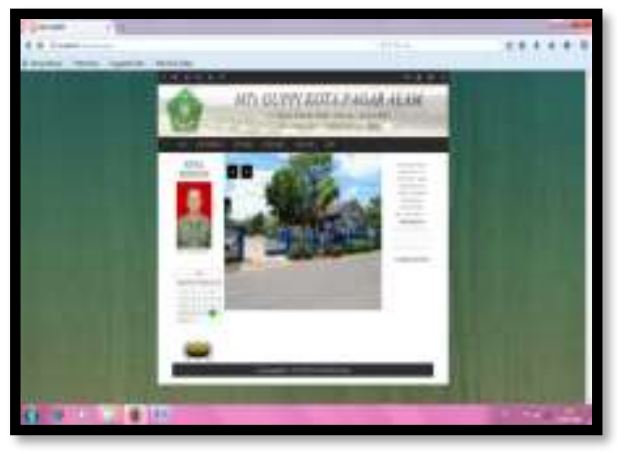

Gambar 7. Halaman Utama

\subsubsection{Halaman Login Admin}

Halaman Login Admin merupakan halaman yang digunakan untuk login ke dalam sistem, sehingga dapat melakukan pengolahan terhadap sistem yang akan di kelola oleh admin

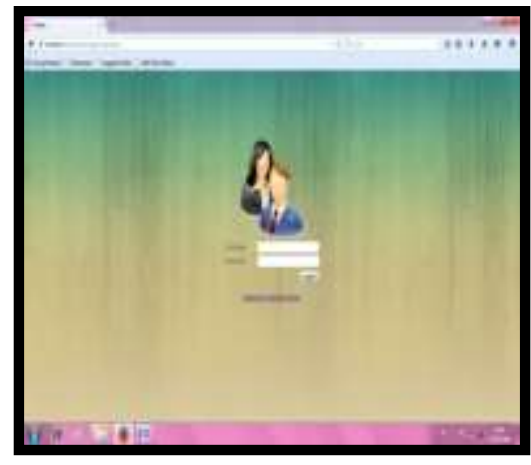

Gambar 8. Halaman Login Admin

\subsubsection{Halaman Menu Admin}

Halaman menu Admin ini berfungsi untuk melakukan pengolaan terhadap sistem sehingga dapat melakukan pengolaan terhadap sistem yang akan di kelola oleh Admin.

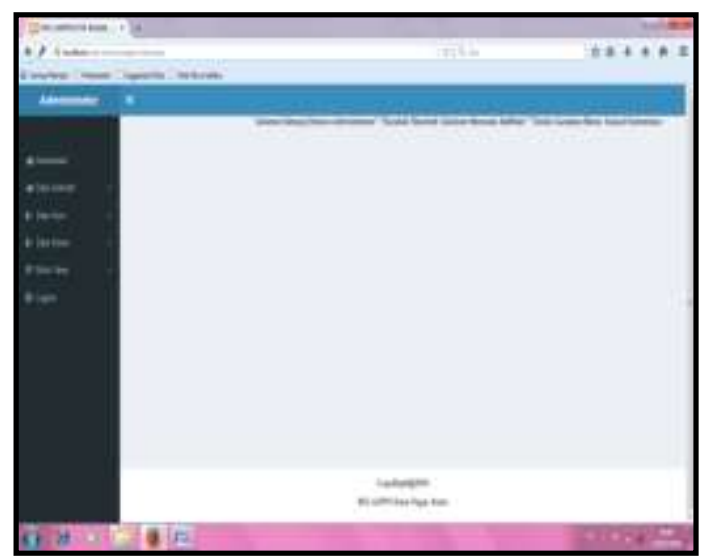

Gambar 9. Halaman Menu Admin

\subsubsection{Input data profil}

Input data profil berfungsi untuk mengisikan data tentang kami dan visi\&misi pada MTs GUPPI. Berikut tampilannya:

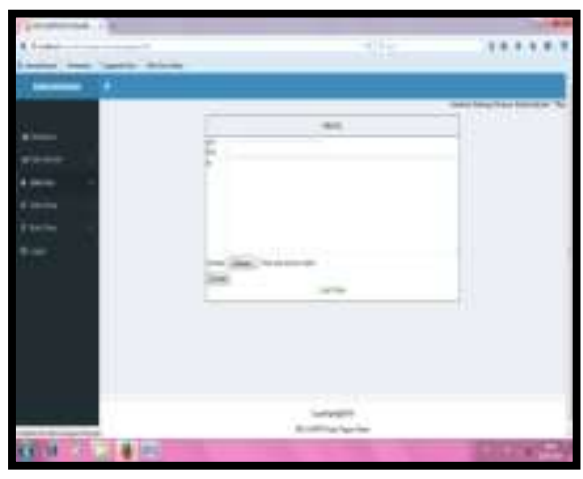

Gambar 10. Input Data Profil

\subsubsection{Output Data Profil}

Output data profil menampilkan hasil dari pemberitahuan tentang kami, visi dan misi yang telah di inputkan. Berikut tampilannya: 


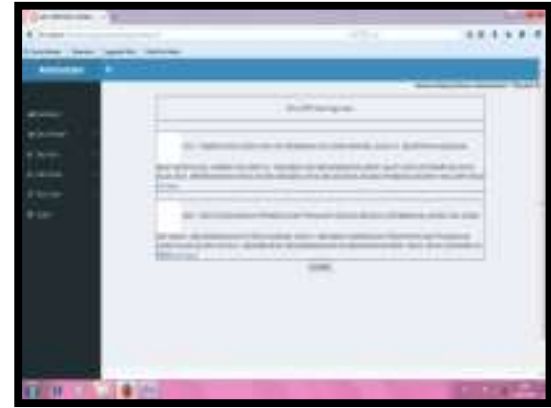

Gambar 11. Output Data Profil

\subsubsection{Input Data Galeri}

Input menu galeri berfungsi untuk memasukan foto kedalam web.

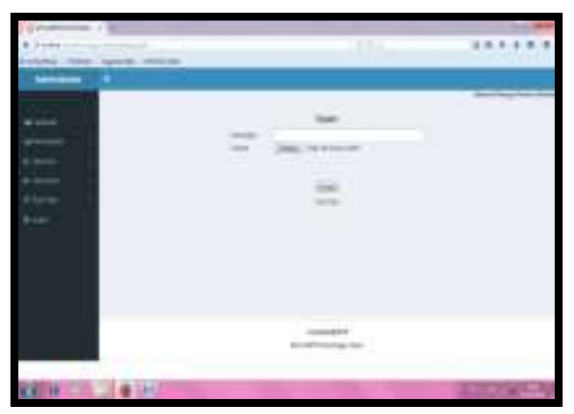

Gambar 12. Input Data Galeri

\subsubsection{Output Data Galeri}

Output data galeri menampilkan hasil dari tambah data galeri

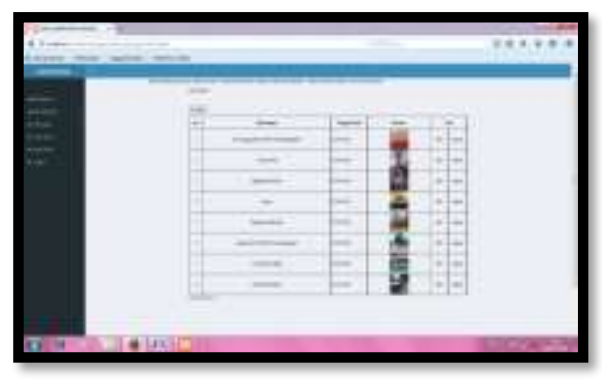

Gambar 13. Output Data Galeri

\subsubsection{Input Data Informasi}

Input data informasi berfungsi untuk memberikan informasi yang ada pada MTs GUPPI, input informasi berupa fasilitas, prestasi, pengumuman dan berita.

\subsubsection{Input Fasilitas}

Input data pasilitas berfungsi untuk memberikan informasi pasilitas yang ada di MTs GUPPI. Berikut tampilnnya

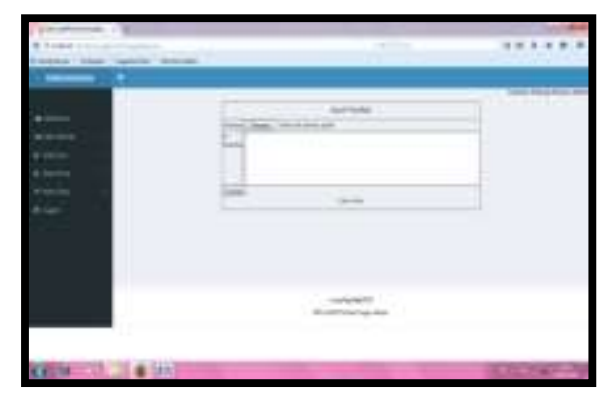

Gambar 14. Input Fasilitas

\subsubsection{Output Fasilitas}

Output pasilitas ini digunakan untuk menampilkan data pasilitas yang ada di MTs GUPPI, outputnya dapat kita lihat pada gambar dibawah ini:

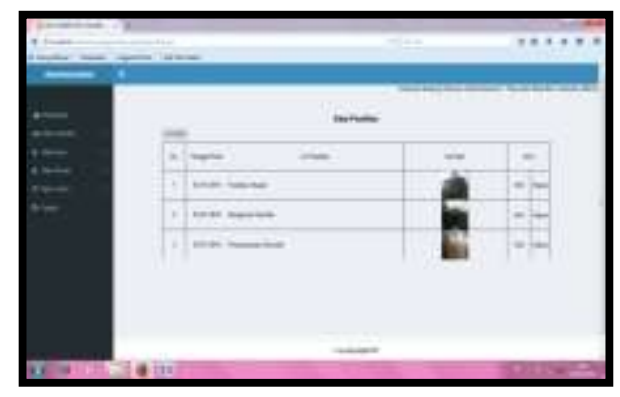

Gambar 15. Output Fasilitas

\subsubsection{Input Prestasi}

Input prestasi digunakan untuk memasukan data siswa yang berprestasi. Input prestasi dapat kita lihat pada gambar dibawah ini:

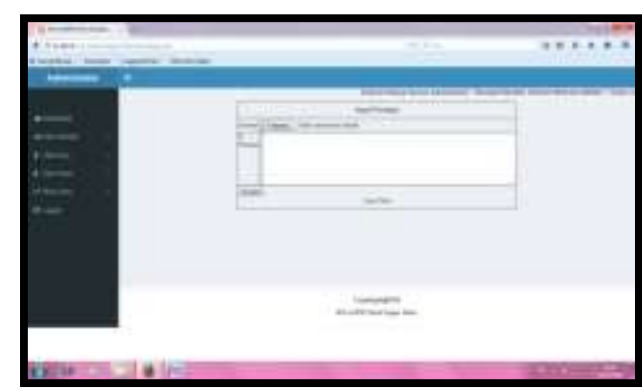

Gambar 16. Input Prestasi 


\subsubsection{Output Prestasi}

Output data Prestasi ini digunakan untuk menampilkan data prestasi di MTs GUPPI, outputnya dapat kita lihat pada gambar dibawah ini:

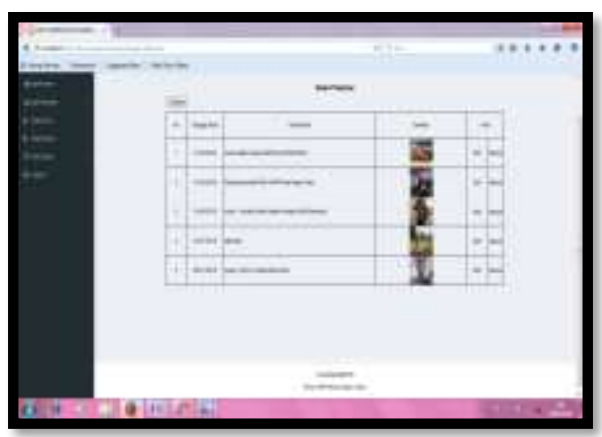

Gambar 17. Output Prestasi

\subsubsection{Input Berita}

Input berita digunakan untuk memasukan berita di MTs GUPPI, menu input berita dapat dilihat pada gambar dibawah ini:

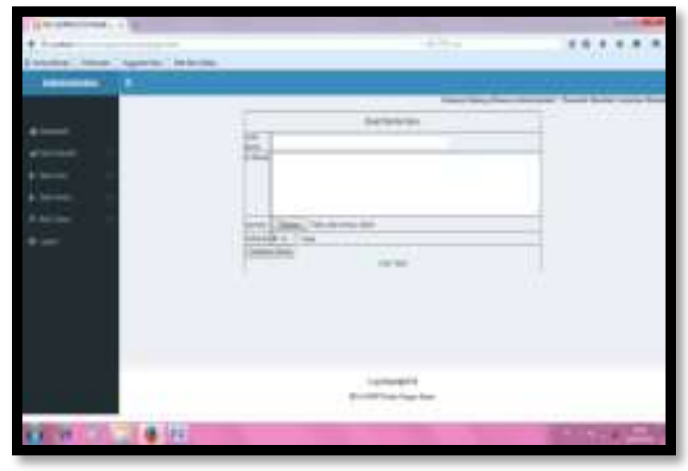

Gambar 18. Input Berita

\subsubsection{Output Berita}

Output data berita ini digunakan untuk menampilkan data berita di MTs GUPPI, outputnya dapat kita lihat pada gambar dibawah ini:

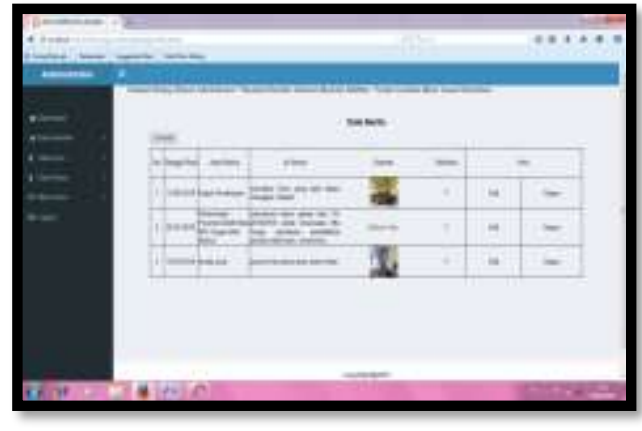

Gambar 19. Output Berita

\section{SIMPULAN}

Berdasarkan hasil penelitian yang penulis lakukan dalam hal membuat Rancang Bangun Sistem Infomasi Pada MTs GUPPI Kota Pagar Alam Berbasis Web, dapat disimpulkan bahwa:

1. Sistem Informasi Pada Mts GUPPI Kota Pagar Alam Berbasis Web sistem dapat membantu MTs Guppi dalam penyampaian sebuah informasi, Mengenai MTs GUPPI

2. Sistem Informasi Pada Mts Guppi Kota Pagar Alam Berbasis Web dapat digunakan MTs GUPPI untuk mempromosikan MTs GUPPI ke masyarakat luas.

3. Untuk memenuhi kebutuhan yang diperlukan, maka diterapkan sistem yang baru yang dapat membantu dalam menyajikan informasi secara cepat dan tepat.

\section{DAFTAR RUJUKAN}

Abdullah, R. (2016). web programming. Jakarta: PT Elex Media Komputindo.

Andi. (2016). Teknik informatika .

Hasyim, N. (2014). Rancang Bangun Sistem Informasi Koperasi Berbasis Web Pada 
Koperasi Warga Baru Mts N 17 JAKARTA. Sistem Informasi Fakultas Sains dan Teknologi Universitas Islam Negeri Syarif Hidayatullah .

Komputer, T. (2012, 05 Kamis). Axure RP PRO 6. Solusi Komputer Anda, p. 1.

Komputer, W. (2011). Mastering CMS Programming PHP \& MySQL. Semarang.

Komputer, W. (2009). Pengebangan We Kreaif Dengan Adobe Dreamwever Cs4.

Komputer, Wahana. (2011). Mastering Cms Programming PHP \& mYsql. semarang.

Madcoms. (2016). pemrograman php dan mysql untuk pemula. Yogyakarta: C.V ANDI OFFSET.

Madcoms. (2016). PEMROGRAMAN PHP dan MySQL untuk Pemula. Yogyakarta: C.V ANDI OFFSET.

Mubarok, H. (2014). Sistem Informasi Akademik Berbasis Web Pada Madrasah Tsanawiyah Syaroful Millah Semarang. Fakultas ilmu computer Universitas Dian Nuswantoro .

Musyawarah, R. (2005). Pemrograman database mysql untuk pemula. Yogyakarta: MediaKom.

Nilasari, S. (2014). Jago Membuat Website Gratis \& Cepat. Jakarta Timur: Dunia Komputer.

Oktavian, N. (2015). Rancang Bangun Website Smp Azharya Palembang.

Pratama, I. P. Sistem Informasi dan Implementasinya. Bandung: Informatka.

Priyanto, H. (2014). Visual Basic. NET Membuat Aplikasi Database dan Program Kreatif. Bandung: Informatika Bandung.

Rohi, A. (2015). Web Programming Is Easy. Jakarta.

Rohmat Taufiq, S. M. (2013). Sistem Informasi Manajemen. yogyakarta.

Rosa. (2014). Perangkat Lunak Bantu. Bandung.
Selemba, I. (2009). Pengembangan Web Kreatif dengan Adobe Dreamweaver. ,Jakarta.

Sulaini, I. (2012). internet untuk pemula. Yogyakarta.

Tohirudin, M. (2011). Pintar Membuat Web dengan jooml. jakarta. 